\title{
FORECAST OF LATVIAN AGE STRUCTURE
}

\section{Leonids PETERSONS}

\author{
Riga Technical University, Riga, Latvia \\ Corresponding authore-mail: Leonids.petersons@rtu.lv,leonids.petersons2@inbox.lv
}

\begin{abstract}
Using the developed mathematical model for forecasting population and age structure in Latvia, the structure of different generations in Latvia has been calculated. This model is based on generally available statistics on the population and birth rates in 19902018. Using these data, we have calculated coefficients that characterize the annual decline in population due to mortality and migration. Using fertility indicators in each fertile group, forecasts of births for the coming years are made, and the estimated population in Latvia is calculated. Forecasts are extrapolated to 2050. The forecast shows that in 2050 the population in Latvia will decrease to one million. Using generic population breakdown by generation, the number of people in each generation in Latvia has been calculated from 2018 onwards. On the basis of this calculation, an overview of the proportions of generations in the Latvian labor market over the years has been developed. Based on forecasts of demographic structure, it is calculated what proportion of workers in Latvia will be formed by popular age group - Millenials. It is shown that this generation's proportion will exceed $40 \%$ of the number of employees already in 2030 .
\end{abstract}

Keywords: age pyramid, age structure, birth rate, demographic, generation structure, population, forecast.

JEL Classification: J240

\section{INTRODUCTION}

The population decline in Latvia has prompted researchers to anticipate the future development of this process. Latvian businessmen and government representatives need data on the dynamics and numbers of individual populations to forecast and plan for the future economy. The author's research is devoted to these problems.

To obtain such data, studies are required:

1. Collect and analyze data on the demographic situation in Latvia.

2. Identify the factors that determine changes in Latvia's generations, their number and proportions.

3. Prepare forecasts of changes in population and structure of the population in Latvia.

Latvian Central Statistics Bureau (CSB) generally available data had used as the main source. 


\section{NUMBER OF POPULATION}

Investigators offer different methods for predicting population and demographic profile - mathematical method, causal method, component method and probability prediction (Preston, Heuveline \& Guillot, 2001). Taking into account the peculiarities of Latvia, the author has chosen the component forecasting method. According to this method, the population of a country is determined by four processes - birth, mortality, emigration and immigration. The following breakdown will search for available information.

Information for birth calculation comes from the CSB (CSB, 2019b). It is used to predict reproduction rates that determine childbirth.

Author has produced a fertility rate forecast, extrapolating it to a linear function based on data from the last 18 years (Kristapsone, 2008). Figure 1 shows this curves, linear extrapolation and real birth rate. Verification this forecast with statistical methods gives information, that differences were inside 2 Sigma region, it means that the extrapolation made with $95 \%$ accuracy. The calculations assume that the birth rate in Latvia will increase to above 2.0 in 2030.

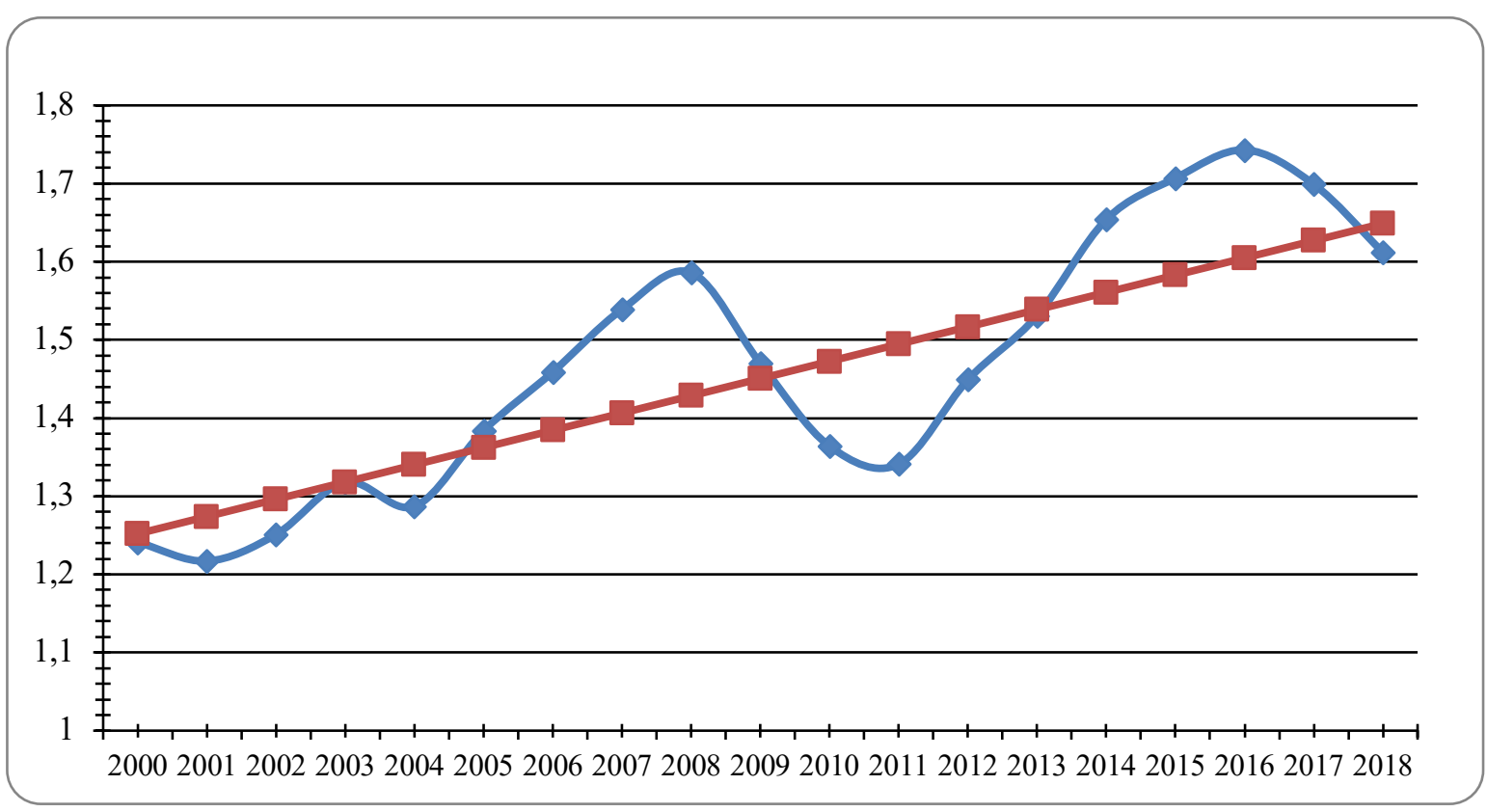

Fig. 1. Forecast of total fertility rate.

Using component forecasting method must take into account the inability to forecast emigration and immigration processes. Both of these, together with mortality, would be calculated by a common factor called survival rate.

The population decline is influenced by migration processes and mortality, which increases after the age of 70. Migration data of CSB is aggregated to whole numbers only, no breakdown by age group. This makes it difficult to separate these data from mortality rates. Author has created a common index called survival rate. It is designed for men $(\mathrm{Kv})$ and women (Ks) separately. This is calculated by dividing the population of each age group by that of the previous year. The estimated survival coefficients and their changes are shown in Figure 2. 


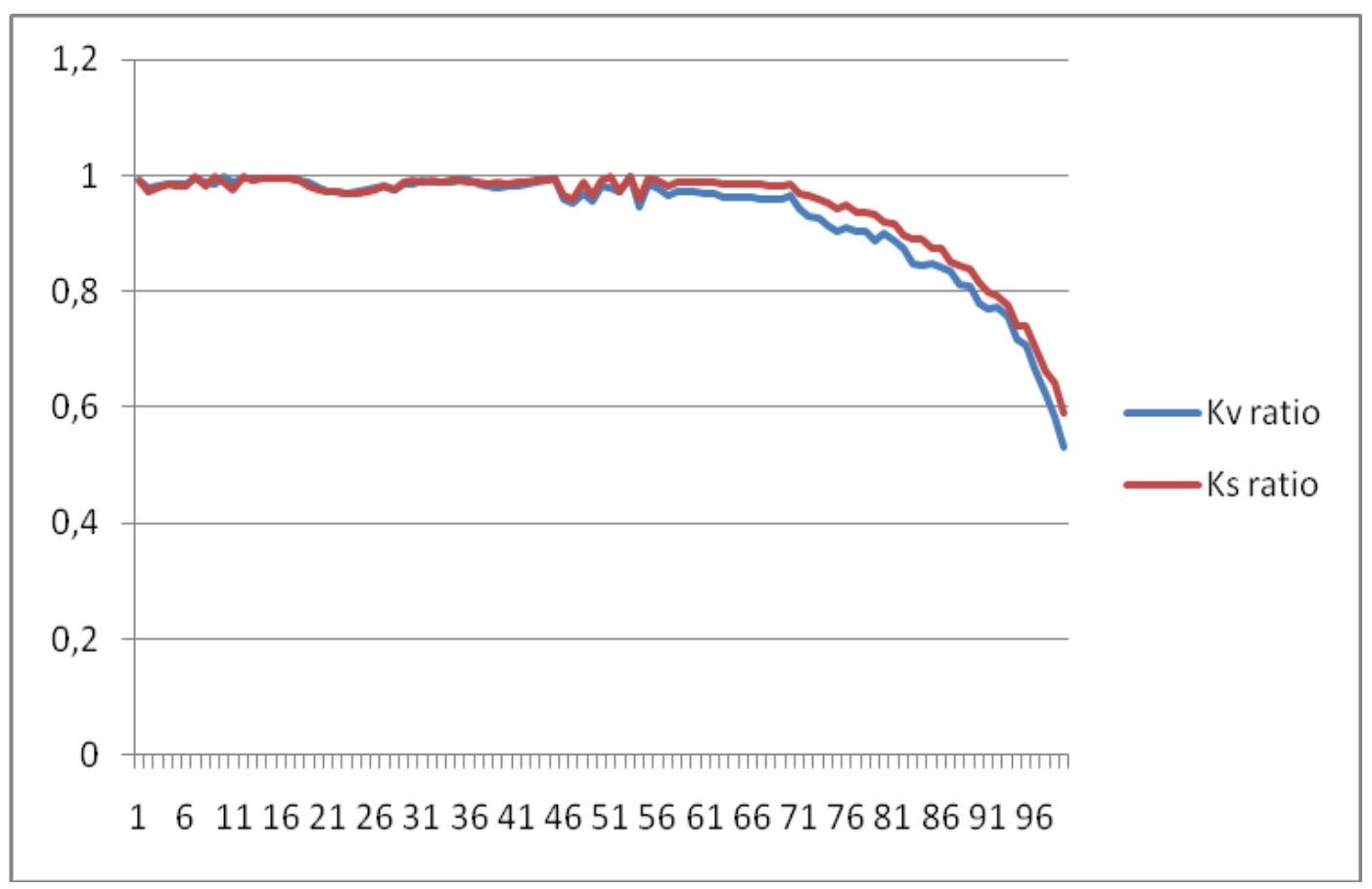

Fig. 2. Survival rates for men (Kv) and women (Ks).

Survival coefficient is calculated used Central Statistical Bureau data, which is under the ISG06 "Men and women in the age structure of the beginning" subdivision (CSB, 2019a). This file contains information on the number of inhabitants at the beginning of year in each age group. It is a table with 4 columns and 100 rows for every year. Transformed file contains data for 26 years from 1990 to 2015 year. This file is used as part of the data set. Next, the data is processed to get us the necessary factors and make predictions.

Survival rate numbers were calculated for 5 consequet generations, average values are get with calculating 5 data sets, conditionally - 5 curves. Last curve extends to the 99 - th year.

In this way, the processing of data and the calculation of the average values get as survival rates for men and women in all age groups from 1 to 99 years shown in Fig. 2.

\section{FORECASTING CALCULATION}

During next, the mathematical model was developed and a series of calculations were made, which provided a complete forecast of the dynamics of each population group over the years

Using previously obtained conversion factors it is carried out the population forecasts. As the input information was used the 2016 -th year's data, anticipation sets extends till 2050 - th year. This is a huge amount of data, look at the main part of each year forecast.

By combining the 2015-2017 population data from the CSB with the results of the forecast, we obtained scores for the Latvian population until 2050, as shown in Figure 3.

From these forecasts we can receive that Latvian population will decrease to 1.5 million in 2031 and up to one million in 2050. 


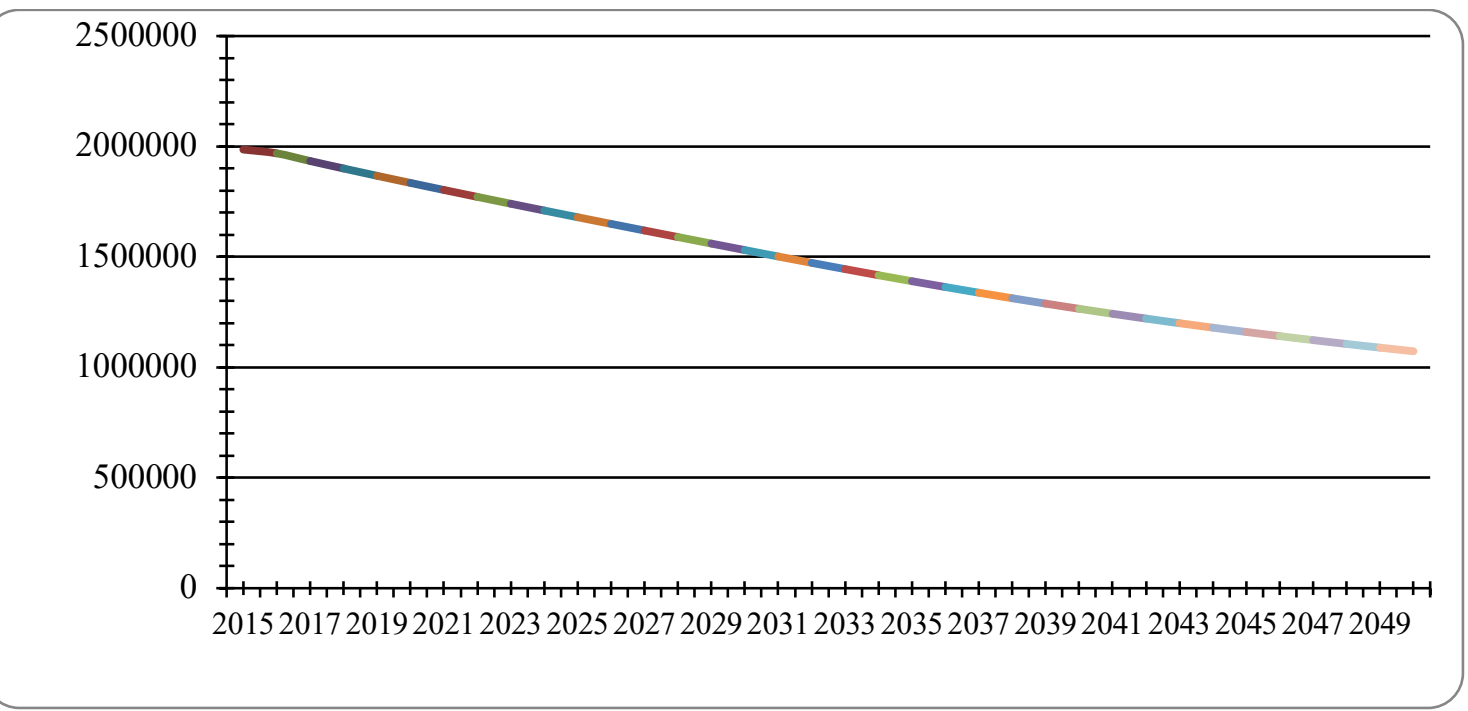

Fig. 3. Forecast of Latvian population until 2050.

To be able to review the resulting large amount of data broken down by year, it is appropriate to establish the pyramid of the age - the image on which we visualized this study. Further changes in the year's best visible "imposing" two pyramid images of each other. Such an 2016 and 2050-year comparison is shown in Figure 4.

Comparing this year, the curve shows that the largest change in a 21 to 85 -year area. However, 0-10 year bands are visible newborn decline to 17000 level.

Red and violet lines left side corresponds to women, blue and green - men.

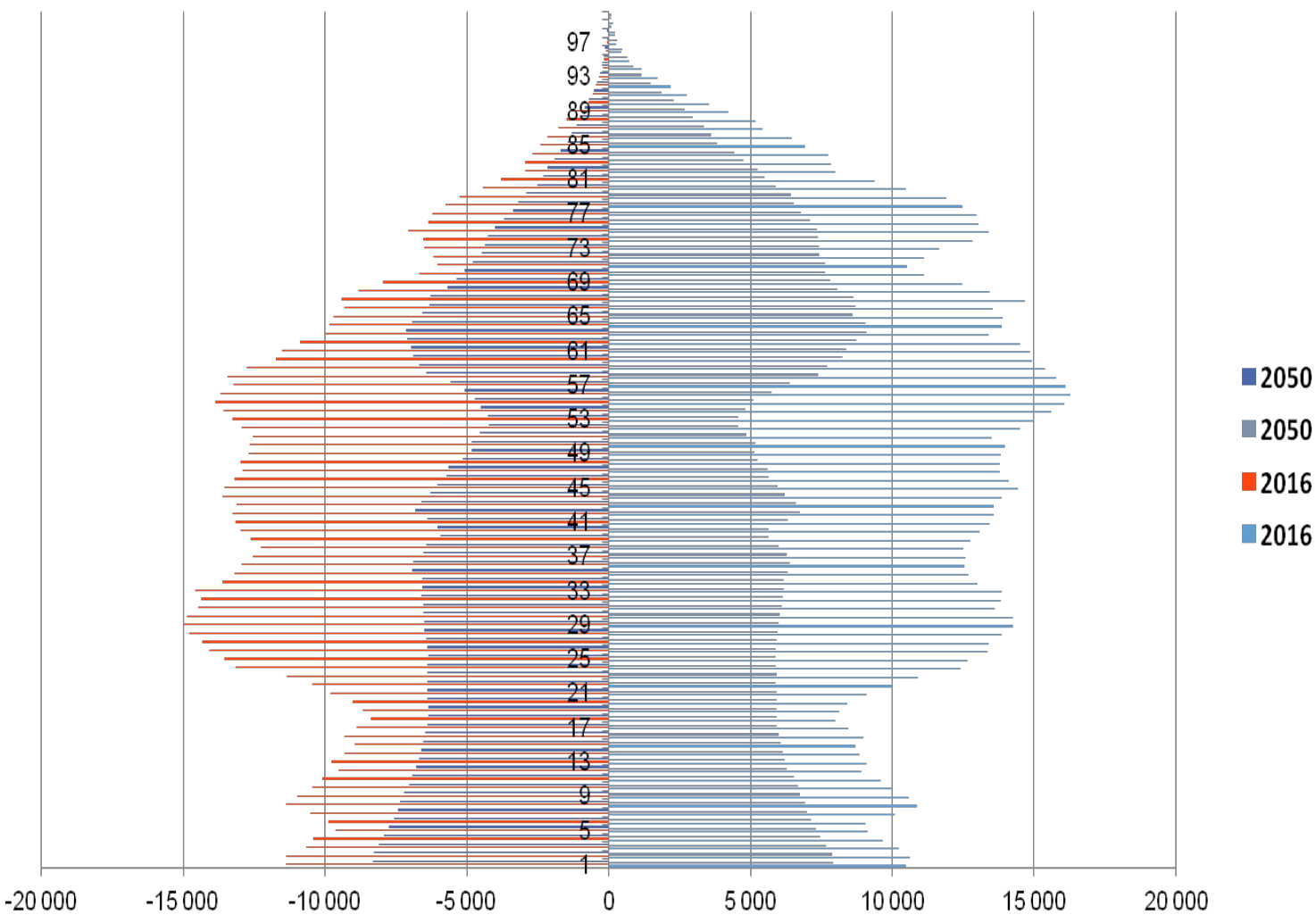

Fig. 4. Demographic Pyramid for 2016 and 2050. 
The obtained forecast data can be used to calculate various society characteristics and their changes over the years. Figure 5 shows a graph of the number of people over the age of 19 each year.

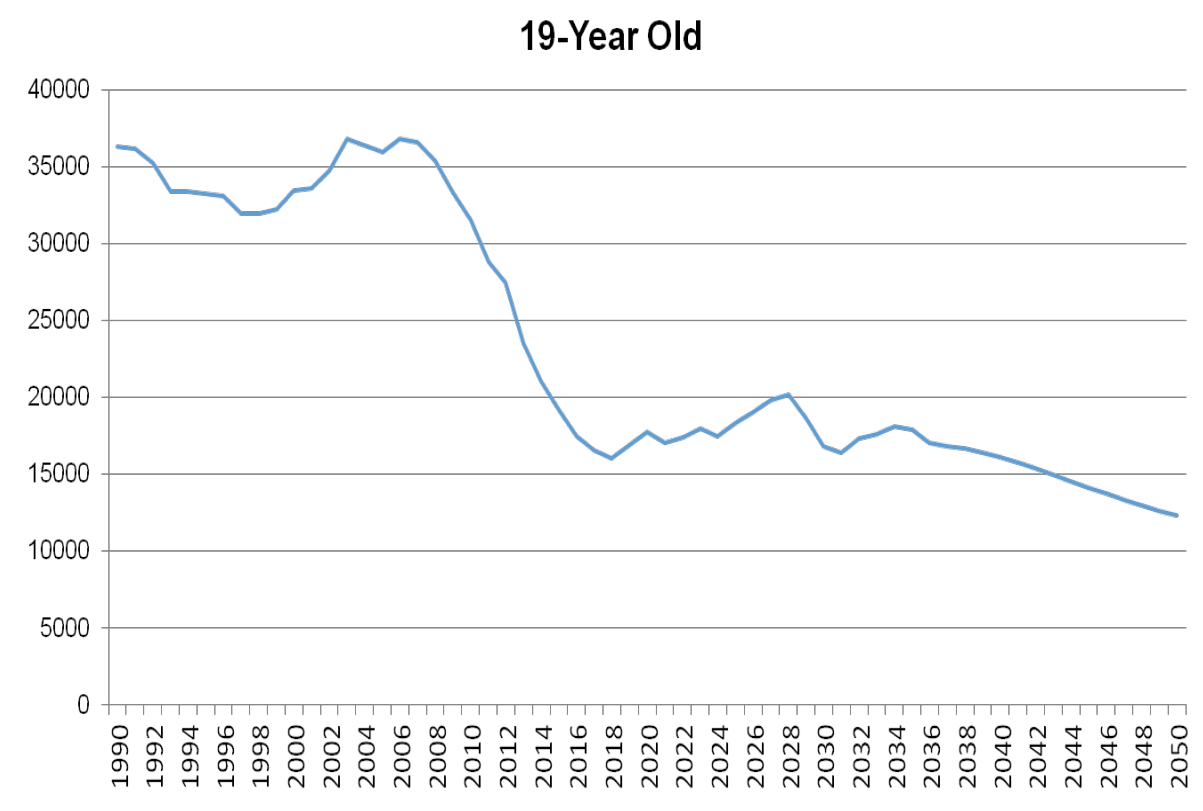

Fig. 5. Number of 19-yer old people in Latvia 1990 - 2050.

This is the high school graduation age. From here you can make forecasts of the number of graduates in Latvia who will apply for university education. Of course, some will go abroad, some will not go to university. It is worth emphasizing that the number of 19year-olds will increase slightly in the next decade, which may create an illusion of improvement. However, after 2028, a drastic fall begins; we should definitely be prepared (Petersons, 2016).

\section{AGE STRUCTURE IN LATVIA}

The developed model also allows calculating the number of population in different age ranges, the so-called generations. Interest in the values, generations of work, leisure and consumption of different generations has increased in the social sciences. Table 1 shows the generation list according to known classification (Rissanen and Luoma-Aho, 2016).

Table 1. Generations.

\begin{tabular}{|l|l|}
\hline \multicolumn{1}{|c|}{ Generations } & \multicolumn{1}{c|}{ Years of Birth } \\
\hline X generation & $1965-1979$ \\
\hline Y generation & $1980-1994$ \\
\hline Z generation & $1995-2010$ \\
\hline ALPHA generation & $2011-2025$ \\
\hline MILLENIALS (Latvia) & $1982-2002$ \\
\hline
\end{tabular}

According to developed model we can calculate percentage part of each generation in Latvia labor market during coming years. Results of calculation were shown in Table 3. 
Table 3. Generations in percent of labor.

\begin{tabular}{|l|l|l|l|l|l|l|l|l|}
\hline \multicolumn{1}{|c|}{ Percent|Year } & \multicolumn{1}{|c|}{$\mathbf{2 0 1 5}$} & $\mathbf{2 0 2 0}$ & $\mathbf{2 0 2 5}$ & $\mathbf{2 0 3 0}$ & $\mathbf{2 0 3 5}$ & $\mathbf{2 0 4 0}$ & $\mathbf{2 0 4 5}$ & \multicolumn{1}{|c|}{$\mathbf{2 0 5 0}$} \\
\hline Baby Boomers & 26.63 & 16.78 & 5.14 & 0.00 & 0.00 & 0.00 & 0.00 & 0.00 \\
\hline X - Generation & 32.10 & 32.78 & 35.60 & 28.10 & 16.87 & 4.91 & 0.00 & 0.00 \\
\hline Y - Generation & 32.63 & 33.83 & 38.49 & 38.92 & 36.27 & 32.67 & 29.85 & 17.47 \\
\hline Z - Generation & 8.65 & 16.61 & 20.76 & 22.59 & 24.49 & 26.92 & 28.91 & 29.58 \\
\hline Alfa - Generation & 0.00 & 0.00 & 0.00 & 10.38 & 22.37 & 35.50 & 33.10 & 34.09 \\
\hline Beta - Generation & 0.00 & 0.00 & 0.00 & 0.00 & 0.00 & 0.00 & 8.15 & 18.87 \\
\hline Total \% & 100.00 & 100.00 & 100.00 & 100.00 & 100.00 & 100.00 & 100.00 & 100.00 \\
\hline
\end{tabular}

Figure 6 shows the proportion of the population of two main generations in the Latvian labor market. These data can be used to make sociological predictions. It is interesting to compare the "millennial" generation with other significant generation, their proportions in Table 3. This would justify the economic and social measures to be taken to stabilize Latvian society and their prosperity.

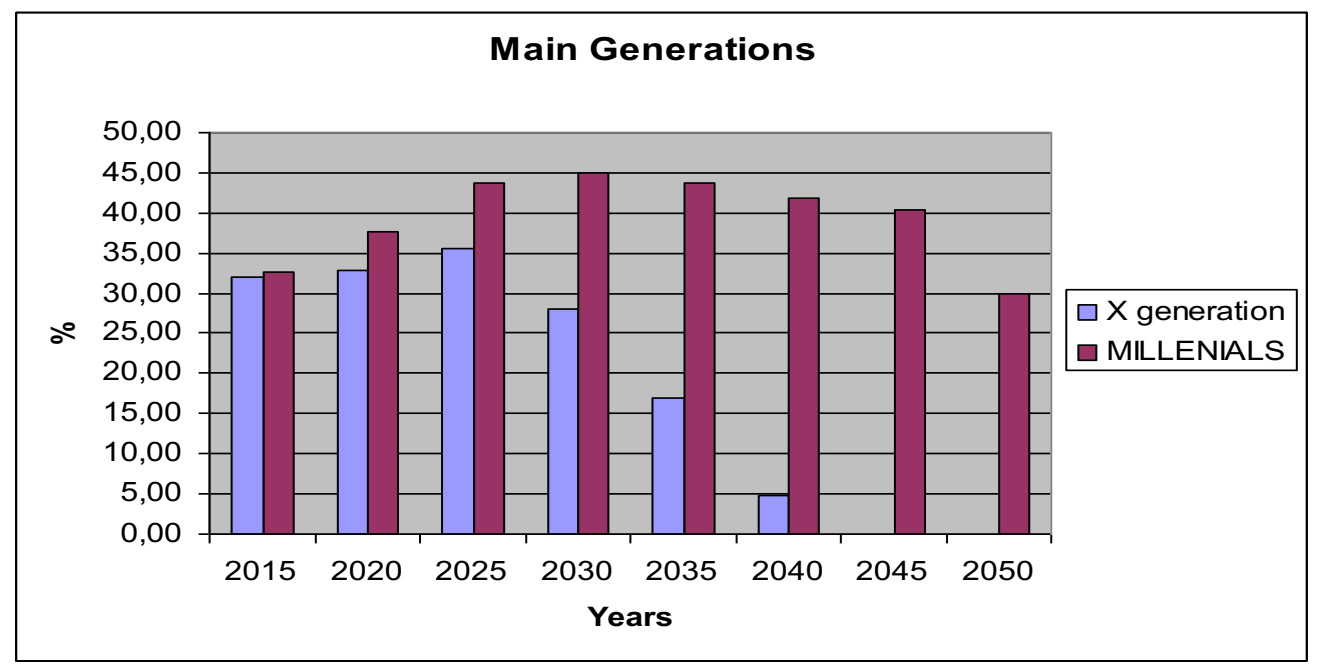

Fig. 6. Proportions of two main generations, $2015-2050$.

It can be seen that in the next few years (2025-2040) the proportion of generation $X$ (born 1965-1979) in the labor market will start to decrease rapidly.

The Millenials (Rissanen H. and Luoma - Aho V., 2016) will play a dominant role. This means that this generation of citizens (born 1982-2002) in Latvia will have a decisive role not only in the economy but also in other areas. This is something that politicians, economists, marketers and other professionals need to consider (Карлсон, 2009).

\section{CONCLUSIONS}

1. The mathematical model has been developed that allows to forecast changes in the population of Latvia

2. Based on the statistical data and using the developed model, the population projection for Latvia up to 2050 has been created

3. The results of the forecast estimate the number and proportions of different generations that can be further used to justify economic, social and political process. 
The developed model allows calculating the number of population in different age ranges, different generations.. These data can be used to make sociological predictions. It is interesting to compare the "millennial" generation with other generations, their proportions. This would justify the economic and social measures to be taken to stabilize Latvian society and their prosperity.

\section{REFERENCES}

CSB. (2019a). CSB Latvia. IDG06. Age structure of men and women at the beginning of the year. Retrieved 20 October, 2019

from http://data.csb.gov.lv/pxweb/lv/Sociala/Sociala_ikgad_iedz_iedzskaits/IS0060.px/table/tableViewLayout 1/?rxid=09cbdecf-2334-4466-bdf7-0051bad1decd

CSB. (2019b). CSB Latvia. IDG04. Birth age coefficients. Retrieved 25 June, 2019 from http://data.csb.gov.lv/pxweb/lv/Sociala/Sociala_ikgad_iedz_dzimst/ID0040.px/?rxid=09cbdecf-23344466-bdf7-0051bad1decd

CSB (2016). Permanent population and age structure at the beginning of the year (by age group 5) 08.06.2016. $\begin{array}{lllll}\text { Retrieved } & 4 & \text { April, } & 2017 & \text { from }\end{array}$ http://data.csb.gov.lv/pxweb/lv/Sociala/Sociala_ikgad_iedz_iedzskaits/IS0022.px/table/tableViewLayout 2/?rxid=cdcb978c-22b0-416a-aacc-aa650d3e2ce0>

Karlson, A. (2009). Swedish experiment in population policy (Shvedskiy eksperiment v demograficheskoy politike). Moscow, Misl.

Kristapsone, S. (2008). Zinātniskā pētniecība studiju procesāa. Rīga, Biznesa augstskola Turība.

Petersons, L. (2016). The Estimated Values of Latvian School Graduates. In: XXV AEDEM International Conference Riga (Latvia), September 1 - 2, 2016. European Academic Publishers.

Preston, S. H., Heuveline, P., Guillot, M. (2001). Demography: Measuring and modeling population processes, Malden: Blackwell Publischers Inc.

Rissanen, H., Luoma - Aho, V. (2016). (Un)willing to engage? First look at the engagement types of millennials. Corporate Communications: An International Journal. Emerald Group Publishing Limited.

\section{AUTHORS' SHORT BIOGRAPHY}

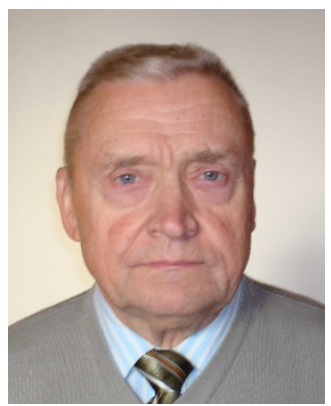

Leonids Petersons is Dr. Sci. Ing. and Assistant Professor of ETF, RTU, Latvia. He received his doctor degree in Moscow Physical and Technical Institute in 1973. L. Petersons also received an MBA degree in 1995 after finishing an International MBA program in Riga Business School in RTU. L.Petersons received an Associate Professor in 2007 at the Riga Technical University. Mr. Petersons provided such courses as Innovations, 5G Technologies, Applied Electronics for ETF RTU students and Strategic Management for RISEBA students. His scientific interests extends from modern Commutication Technologies till Demographic problems in Latvia and Europe. 